\title{
SEGURANÇA PÚBLICA: A POPULAÇÃO NO PLANEJAMENTO URBANO
}

\author{
JOANITA ARAÚJO ESPANHOL \\ Mestra em Segurança Pública pela Universidade Vila Velha. Especialista em Direito e Processo do Trabalho, Direito Civil \\ e Empresarial e em Direito Digital e Compliance. Graduada. Atualmente é professora no Instituto Federal de Educação, \\ Ciência e Tecnologia do Espírito Santo. \\ País: Brasil Estado: Espírito Santo Cidade: Colatina \\ Email de contato: joanita@ifes.edu.br ORCID: https://orcid.org/0000-0001-8483-9409
}

\section{MICHELLY RAMOS DE ÂNGELO}

Arquiteta e urbanista, pós-doutorado pelo Instituto de Arquitetura e Urbanismo da Universidade de São Paulo, com estágio no Centre Lillois d'Études et de Recherches

Sociologiques et Économiques da Université des Sciences et Technologies de Lille. Autora de Louis-Joseph Lebret e a Sagmacs: A formação de um grupo de ação para o planejamento urbano no Brasil (2012)

País: Brasil Estado: Espírito Santo Cidade: Vitória Email de contato: michellyr@hotmail.com ORCID: https://orcid.org/0000-0001-5921-3199

\section{Contribuição de cada autora:}

Ambas tiveram participação na elaboração da proposta da pesquisa, orientação e revisão do conteúdo

\section{RESUMO}

A Segurança Pública é um tema que ocupa os debates da sociedade, sendo que a ocorrência reiterada de atos de violência e os índices de criminalidades estão presentes nessas discussões. Situação que pode ser diagnosticada e minimizada com um planejamento urbano adequado que busque a qualidade de vida e a segurança da população. O Plano Diretor Municipal (PDM) constitui-se como um dos principais instrumentos de planejamento municipal, palco de debates de fatores relacionados à segurança pública. Este estudo apresenta como pergunta: Como a participação popular, experimentada no processo de revisão do PDM do Município de Vila Velha-ES, relaciona a vulnerabilidade socioambiental à segurança pública? Para tanto, foi conduzida uma pesquisa qualitativa, utilizando as técnicas de análise de conteúdo com o apoio do software Iramuteq. Os resultados indicaram que as sugestões da população participante relacionam a condição de vulnerabilidade às necessidades vivenciadas com questões preventivas de segurança pública.

Palavras-chave: Planejamento urbano. Prevenção. Exclusão territorial. Exclusão social. Criminalidade.

\section{ABSTRACT PUBLIC SAFETY:POPULATION IN URBAN PLANNING}

Public Security is a theme that occupies the debates of society, the repeated occurrence of acts of violence and the crime rates are present in these discussions. Situation that can be diagnosed and minimized with proper urban planning that seeks the quality of life and safety of the population. The Municipal Master Plan (PDM) is 
one of the main instruments of municipal planning, the stage of debates on factors related to Public Security. This study presented as a question: How does popular participation, experienced in the PDM review process of Vila Velha-ES, relate social and environmental vulnerability to public safety? To this end, a qualitative research was conducted using content analysis techniques with the support of IRaMuTeQ software. The results indicated that the suggestions of the participating population relate the condition of vulnerability to needs experienced with preventive issues of public security.

Keywords: Urban planning. Prevention. Territorial exclusion. Social exclusion. Crime.

Data de recebimento: 01/06/2020 - Data de aprovação: 07/03/2021

DOI: $10.31060 /$ rbsp.2021.v15.n2.1250

Neste artigo abordou-se políticas públicas de segurança, como ações e decisões do governo pautadas nas demandas e nos problemas da sociedade, que refletiam na manutenção e na estabilidade da ordem pública. O que se propôs foi analisar como a participação popular e seus anseios, no âmbito de discussão do Plano Diretor Municipal (PDM), podem contribuir para ações que repercutam na segurança pública.

Destaca-se que essas ações podem ser inseridas no planejamento urbano desenvolvido pelo município por meio do PDM. Algumas ações de caráter preventivo são citadas por Magalhães (2008) e Xavier (2012), como: desocupação de áreas de preservação ambiental, de revitalização de espaços públicos e de reurbanização de locais com focos de criminalidade; planejamento e reforma urbana; mapeamento das áreas e das espécies de conflitos; e uma gama de políticas sociais integradas que promovam a cidadania e ofertem serviços básicos.

Assim, delimitou-se o tema em torno da pergunta: Como a participação popular, experimentada no processo de revisão do PDM do Município de Vila Velha-ES, relaciona a vulnerabilidade socioambiental com a segurança pública no que tange aos apontamentos de suas necessidades a fim de contribuição para a formulação de políticas públicas de segurança?

A pesquisa, inicialmente, pretendia abarcar todo o processo de revisão do PDM de Vila Velha-ES, contudo, teve seu recorte limitado pelo fator tempo: o Município não procedeu a conclusão de todas as etapas, tendo efetivado, até o começo da presente análise, somente a fase da leitura comunitária.

O banco de dados, contendo as indicações e a participação da população Vila Velhense, foi construído a partir das informações disponibilizadas pela Prefeitura Municipal de Vila Velha-ES em seu site institucional e utilizando o método qualitativo de análise de conteúdo por meio do software Iramuteq.

Isso posto, pretendeu-se discutir o tema revisão do Plano Diretor Municipal com fins contributivos para ações de política de segurança a partir da perspectiva dos cidadãos participantes da revisão do PDM de Vila Velha-ES.

\section{A RELAÇÃO ENTRE VIOLÊNCIA E VULNERABILIDADE}

Viver nos centros urbanos não só é um desafio para seus habitantes como também é para os governantes, que precisam gerir os problemas que circundam o desenvolvimento e o crescimento das cidades. Para 
Farias (2005), o aumento do número de habitantes e o crescente processo de urbanização vêm acarretando degradação da vida urbana. Essa degradação tem impacto na vida humana, seja quando interrompida abruptamente por ato de violência seja quando se é alvo de crimes que não terminam em morte, mas infringem o direito à dignidade humana. É no meio ambiente urbano que ocorre grande parte das lesões ao direito da dignidade humana e ao direito da segurança". A promoção da dignidade humana é "[...] postulado fundamental da ordem jurídica brasileira" (FARIAS; ROSENVALD, 2015, p. 164) e deve pautar condutas e políticas públicas de segurança.

Para que haja desenvolvimento pleno do ser humano há pressupostos, ou seja, requisitos mínimos para se viver com dignidade, dentre eles a proteção da personalidade², que se projeta em assegurar os atributos físicos, psíquicos e morais do homem (FARIAS; ROSENVALD, 2015). Atentar contra os atributos da personalidade humana é ato de violência (CARDIN; MOCHI, 2014).

Segundo a Organização Mundial da Saúde, violência constitui:

[...] a utilização intencional de força ou poder físico, por ameaça ou de fato, contra si mesmo, contra outra pessoa ou contra um grupo ou comunidade que resulta em ou tem alta probabilidade de resultar em ferimentos, morte, dano psicológico, mau desenvolvimento ou privação. (OMS, 2002, p. 5).

A violência acaba por estar presente na vida íntima ou no desenvolvimento de atividades coletivas. E, tão importante quanto agir no pós-violência, é promover ações que a previnam ao entender suas causas.

Nesse sentido preventivo, Caldeira (2000) associa violência às transformações urbanas, que produzem um padrão espacial de segregação e exclusão social, aliadas à fragilidade dos direitos civis. Transformações urbanas não ocorrem da mesma forma para toda a população, a urbanização das periferias, por exemplo, pode ser resultado de especulações imobiliárias com a consequência de ilegalidade dos lotes e das construções.

Na presença de irregularidades na documentação dos lotes ou ilegalidade dos lotes, não há como conseguir financiamentos ou ter acesso a direitos básicos. Direitos que deveriam ser ofertados pelo poder público, como água tratada, saneamento básico, ruas pavimentadas, dentre outros, emergindo, a partir disso, a segregação espacial ao dividir e fragilizar os habitantes de uma mesma cidade dentro de várias cidades.

Segundo Villaça (2011), a segregação urbana não deve ser vista ou estudada pelo viés apenas de centro versus periferia, mas compreendida dentro do contexto que se propõe investigar. Exemplificando, o autor menciona a formação de condomínios fechados, que podem estar inseridos em ambientes de separação não em relação à gênese da violência, mas na fuga em busca por proteção contra a violência.

Nesse cenário de segregação espacial, não os de condomínios fechados, os habitantes do espaço marginalizado não conseguem ter a efetividade de direitos civis essenciais e fundamentais, como a vida ou o "simples" ir e vir, tantas vezes impedido por "toques de recolher", tiroteios, falta de transporte e ruas alagadas.

Farias (2005, p. 171) afirma que "a cidade mal organizada e mal planejada pode ser fonte ou lente de aumento da violência e da criminalidade". Na cidade segredada, "a falta de infraestrutura e a precariedade dos serviços públicos concorrem facilmente para a formação de delinquência" (CARMONA, 2014, p. 107).

1 Por exemplo, as capitais brasileiras concentraram 26\% dos assassinatos do país, em 2015 (LIMAS, 2016).

2 Referem-se a abordagens do Direitos da Personalidade, e não a conceitos relacionados psicologia. 
Outra vertente para a compreensão da violência é apontada por Rolnik (2000, p. 183), ao afirmar que: "'a exclusão territorial'3 faz indivíduos, famílias e comunidades particularmente vulneráveis, abrindo espaço para a violência e o conflito". Defende, ainda, que no cenário do urbanismo de risco ${ }^{4}$ as terras destinadas para moradia dos pobres são, normalmente, aquelas marcadas por características ambientais de fragilidade, perigosas e de difícil ocupação, com encostas íngremes à beira de córregos e áreas alagadiças. Tal situação desrespeita os direitos civis e expõe a vida dos moradores, contribuindo para configuração de um quadro de exclusão socioespacial.

A pobreza, a miséria e a precariedade de moradias muitas vezes estão inseridas num contexto de exclusão social e territorial, mas não são apresentadas pela literatura como fatores desencadeadores de violência. Na visão de Carmona (2014), a pobreza e a miséria, em si, não são causas de violência, mas sim a sua condição, vulnerabilizando principalmente a juventude ${ }^{5}$ e sua inserção na delinquência. Por fim, o autor, defende que a segregação urbana exerce sim efeito sobre fatores sociais e acaba por gerar violência.

O termo vulnerabilidade admite várias possibilidades, como a incapacidade ou a fragilidade de alguém, de espaços ou algo em circunstâncias especiais (SILVA R., 2010). O conceito adotado na presente pesquisa é aquele que relaciona vulnerabilidade socioambiental à violência urbana. Vulnerabilidade socioambiental alia as precárias condições de vida e a proteção social à degradação ambiental, produzindo, simultaneamente, condições de vida precárias e ambientes deteriorados, expressando-se também como menor capacidade de redução de riscos e baixa resiliência (FREITAS et al., 2012).

Ressalta-se, entretanto, que a concepção de resiliência, como a capacidade de um ambiente ou sociedade de voltar às condições anteriores após serem impactadas/vitimadas por um evento de caráter extremo, nem sempre deve ser inserida no contexto da urbanização dos países não desenvolvidos, já que não se deve recompor as condições pré-existentes, pois em sua grande parte são extremamente excludentes, injustas e degradantes (MENDONÇA, 2017).

O contexto de vulnerabilidade socioambiental é complexo. Silva, R. (2010) relaciona violência urbana à vulnerabilidade socioambiental por meio da exclusão social, apontando que as zonas de exclusão social são usualmente áreas com alto grau de vulnerabilidade ambiental e, assim, algumas áreas tornam-se mais vulneráveis aos conflitos violentos e passam a ser consideradas áreas de risco. Logo, o conceito de vulnerabilidade envolve "um conjunto de fatores que pode diminuir ou aumentar o risco no qual o ser humano, individualmente ou em grupo, está exposto nas diversas situações da sua vida” (ESTEVES, 2011, p. 69).

Todos os fatores (exclusão social, exclusão territorial, segregação urbana, urbanismo de risco) elencados pelos autores citados compõem as características de um ambiente onde há vulnerabilidade socioambiental. "O processo de deterioração do espaço social e institucional ${ }^{6}$ contribui para tornar essas áreas cada vez mais vulneráveis à violência, transformando-as rapidamente em áreas de risco" (SILVA, R., 2010, p. 12).

3 É a negação (ou desrespeito) dos direitos que garantem ao cidadão um padrão mínimo de vida, assim como a participação em redes de instituições sociais e profissionais (ROLNIK, 2000, p. 176).

4 Segundo Rolnik (2000, p. 174), o urbanismo de risco é aquele marcado pela inseguridade, quer do terreno quer da construção, ou ainda da condição jurídica da posse daquele território.

5 Situação que tornam a juventude vulnerável à violência e ao crime: "[...] a baixa oferta de emprego e o subemprego, especialmente o tráfico de drogas, [...] fácil acesso às armas de fogo leves, [...] cortiços e favelas por servir de refúgio e esconderijo de grupos criminosos perigosos" (CARMONA, 2014, p. 109).

6 A autora traz como degradação do espaço e causa da violência urbana os processos desiguais de ocupação segregada do espaço urbano, já como degradação institucional, as relações de poder assimétricas e informais que acontecem nas comunidades de baixa renda com os cidadãos de segunda classe, e estes, por sua vez, são os moradores sem acesso às instituições de proteção e bem-estar do Estado, e a violência torna-se um instrumento para alcançar alguns resultados, como justiça, segurança e ganhos econômicos (SILVA R., 2010). 
A vulnerabilidade socioambiental relaciona-se à segurança pública, na medida que se busca a compreensão de fenômenos como violência, crimes e desastres, num raio de amplitude maior do que a repressão. Silva, R. (2010, p. 9) afirma que "o risco de ocorrer um ato violento é maior em áreas de vulnerabilidade social e ambiental, [...] e, estas são marcadas pela exclusão social, fator fundamental para o aumento da violência urbana”.

Dessa forma, baseada na exposição de estudiosos sobre o tema abordado, fatores presentes na vida urbana como a exclusão social, a exclusão territorial e a segregação espacial são componentes de um ambiente com vulnerabilidade socioambiental. A exposição na Figura 1, fundamentada na exposição da literatura, permite associar vulnerabilidade à segurança pública.

\section{FIGURA 1}

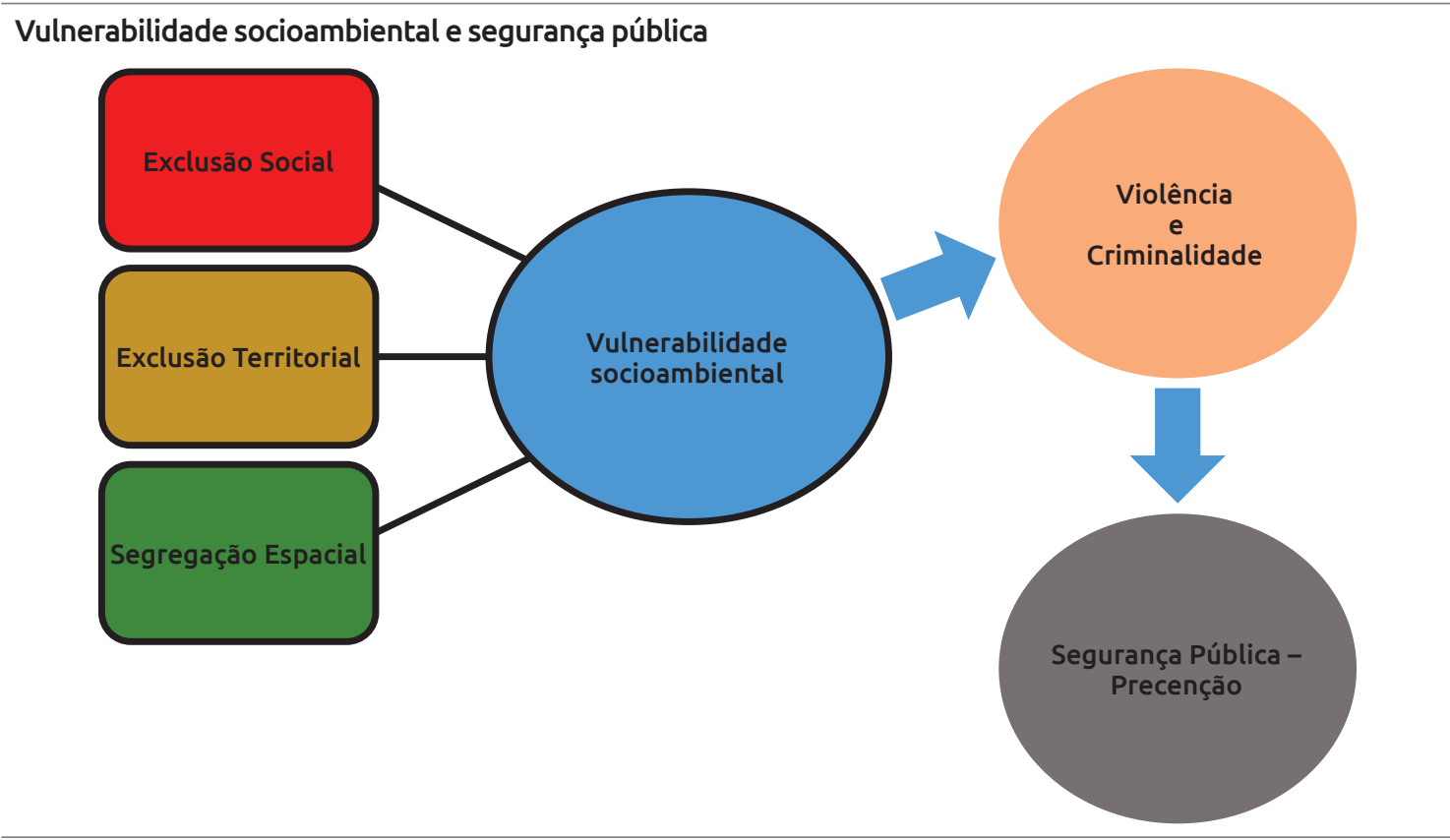

Fonte: Elaborado pela autora de acordo com o referencial teórico.

Destaca-se que os fatores citados na Figura 1 podem ser identificados pelos cidadãos que os vivenciam no processo de Revisão do PDM. E, se forem trabalhados pelo município, principal ente federativo responsável pela execução da política urbana ditada pela Constituição Federal de 1988, cumprirão o ditame do Estatuto da Cidade, o qual enfatiza que as normas de regulação de uso da propriedade urbana devem ser elaboradas em prol da segurança e do bem-estar dos cidadãos.

Se ações de políticas públicas forem direcionadas para programas e projetos que diminuam a vulnerabilidade desses cidadãos, que convivem com os problemas urbanos identificados, pode haver uma significativa melhoria em termos de segurança pública. Carmona (2014) cita a transformação da cidade de Bogotá, na Colômbia, que convivia com sérios problemas de violência no início da década de 90, chegando a registrar 80 homicídios (mortes violentas) por 100 mil habitantes e conseguiu reduzir, significativamente, esse número para 22,7 em 2009.

O autor destaca ainda que a violência e a criminalidade de Bogotá foram reduzindo com a implementação de política pública clara e sustentável e com a participação da população, citando como exemplo as 
seguintes ações: arborização da cidade, recuperação de espaços públicos e de entornos deteriorados, gestão das informações sobre violência e delinquência, atenção especial a grupos vulneráveis.

O exemplo citado é fruto de um conjunto de ações voltadas para uma população que sofria com problemas de segurança pública e que enxergou a saída numa série de medidas preventivas e não exclusivamente em ações repressivas. Tais medidas devem ser associadas a um planejamento urbano adequado à realidade de cada cidade, com normas efetivas instituídas e elaboradas em conjunto com a população. A existência da nova ordem urbanística constitucional, compreendida como "promoção da dignidade da pessoa humana" (CARMONA, 2014, p. 327) e com fins de confrontação e resolução de conflitos (FERNANDES, 2013), pode atuar na prevenção da violência.

De acordo com a revisão da literatura apresentada, existem alguns grupos mais suscetíveis à violência e à criminalidade, os que vivenciam e/ou estão no cenário da vulnerabilidade. Ações que envolvam planejamento urbano podem diminuir a condição de vulnerabilidade e reduzir os números da violência. Observa-se, portanto, a associação entre planejamento urbano inadequado ou a sua ausência e a segurança pública. Situação que pode ser discutida no âmbito da formação do PDM, principal instrumento do planejamento urbano municipal.

\section{ANÁLISE E DISCUSSÃO DOS RESULTADOS}

A Leitura Comunitária constituiu-se de onze eventos realizados entre os dias 28 de março e 6 de junho de 2016, sendo cinco fóruns regionais, cinco seminários e uma audiência pública (VILA VELHA, 2016). Concomitantemente, contou com a participação on-line da população por meio de uma plataforma participativa disponível no site oficial da prefeitura de Vila Velha-ES (disponível em: pdm.vilavelha.es.gov.br).

Na plataforma participativa on-line, dentro da aba intitulada "Melhore sua Cidade", o internauta era convidado a participar expondo ou avaliando sugestões que poderiam ser realizadas por tema ${ }^{8}$ e por região' ${ }^{9}$, bem como efetuar somente curtidas nas sugestões de outros participantes.

Com os dados encontrados, foi possível construir as análises. Foram analisados 355 comentários (on-line) postados até 2 de novembro de 2017, que compõem parte da participação popular no PDM de Vila VelhaES, o que possibilitou estabelecer as relações entre as variáveis estudadas.

Os comentários foram organizados em um único corpus que foi submetido ao software Iramuteq com os métodos: Nuvem de Palavras, Classificação Hierárquica Descendente (CHD) e Gráfico de Similitude.

Inicialmente, por meio da Nuvem de Palavras representada pela Figura 2, analisou-se os termos que organizados graficamente apresentavam maior frequência (CAMARGO; JUSTO, 2013). Dessa forma, o software aponta as palavras que mais se repetiram no corpus da pesquisa, fornecendo um resumo do material (corpus) analisado. Trata-se de um resumo, pois em destaque e mais centralizadas estão as palavras de maior frequência, gradualmente; em seguida, aparecem as de menor frequência em tamanho menor e mais periféricas.

7 Constitui a segunda etapa do processo de revisão do PDM de Vila Velha-ES

8 O conteúdo a compor o novo PDMVV foi dividido em temas: mobilidade urbana, economia, patrimônio histórico, meio ambiente, infraestrutura urbana, uso do solo e habitação.

9 O município de Vila Velha-ES é composto por cinco regiões administrativas. 
Considerando as palavras em destaque na Figura 2, observam-se alguns substantivos como poder, praia, bairro e região, o que indica sua importância e representatividade no corpus textual.

\section{FIGURA 2}

Resultado da análise do gráfico de Nuvens de Palavras (Vila Velha-ES, 2017)

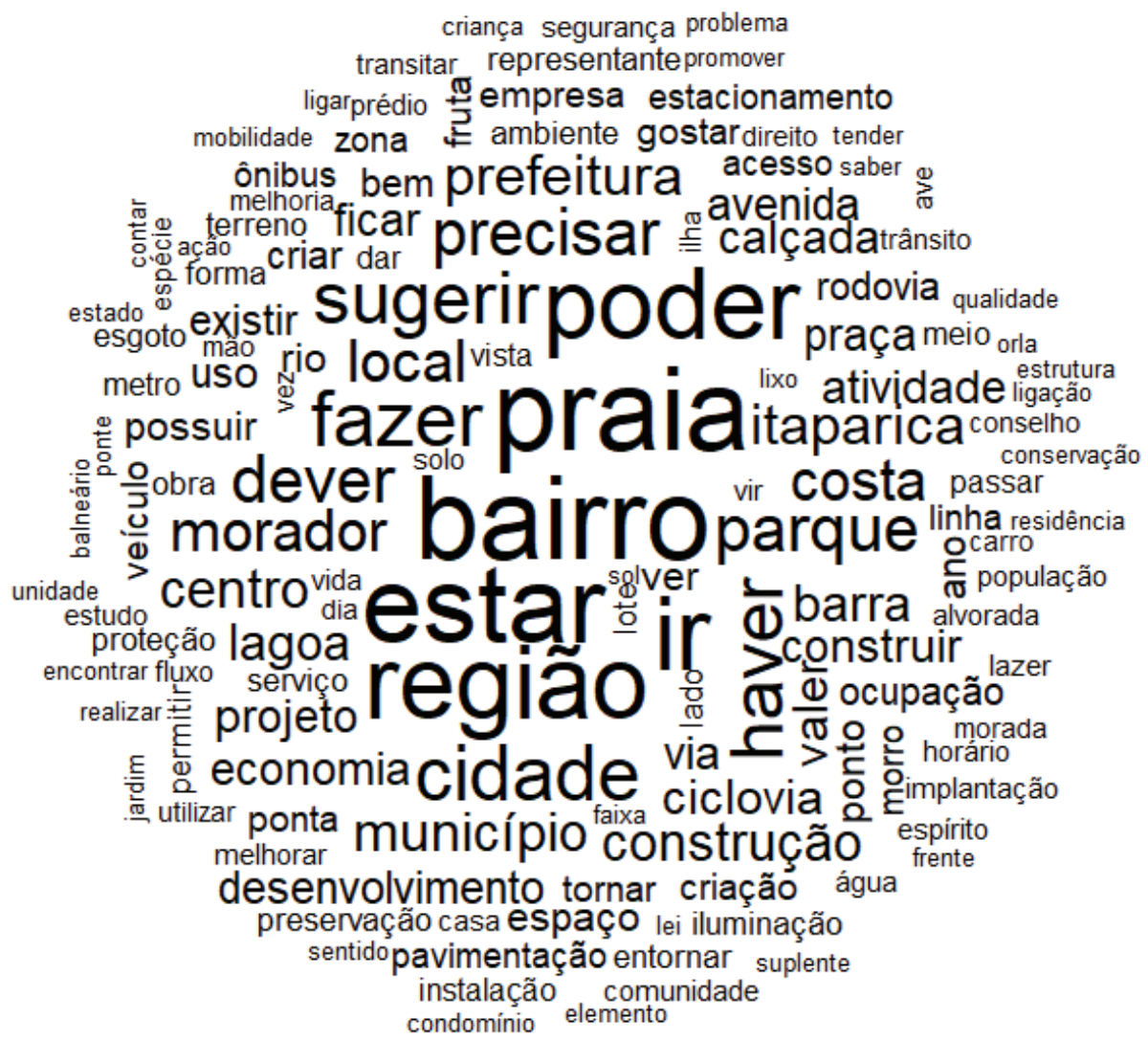

Fonte: Dados da pesquisa.

Essa descoberta, do centro a partir da palavra bairro, no sentido vertical/norte, sugere que a população visualiza a sua realidade a partir de seu bairro. Isso indica necessidades imediatas e problemas pontuais, aponta que essas necessidades estão relacionadas ao poder executivo, já que o nome prefeitura aparece em um tamanho um pouco menor, contudo próximo a poder e a representante.

\footnotetext{
Morada da Barra. Lagoa Jabaete, que deveria ser ponto turístico ou de passeio, não recebe atenção dos órgãos da prefeitura e demais órgãos de preservação. Está secando por não ter controle de retirada de água do meio para irrigações de plantações em torno e nem preservação da área para recuperação. Além da subida para o xuri, está sendo retirada de terra em área de matas e invasões de casas por pessoas indevidamente e em estado de perigo para vida. A região já se encontra em guerra de espaço sem devida segurança e atenção para melhorias dos bairros que ali em torno já se encontram, e cada dia mais tendo pessoas a ocupar áreas indevidas. (Participante $n^{\circ}$ 6, grifo nosso).
}

A fala apresentada do Participante $n^{\circ} 6$ aponta conhecimento de necessidades sobre o bairro Morada da Barra e, mais do que isso, aponta as forças (MARICATO, 2014) que atuam sobre ele. A fala ainda aponta a omissão do poder público frente às questões ambientais em detrimento das econômicas, além da pressão popular e da capacidade da sociedade civil em monitorar e fiscalizar o cumprimento da lei (SOUZA, 2010), 
o que pode fazer frente à ineficiência da administração pública. Por fim, os dizeres entrelaçam-se com a segurança pública ao mencionar "guerra de espaços, sem segurança em áreas ocupadas indevidamente", cenário propício e vulnerável (SILVA R., 2010) à violência urbana (ROLNIK, 2000)

Em seguida, na Nuvem de Palavras (Figura 2), em menor tamanho surgem as palavras criança, segurança e problema, indicando a preocupação da população com a segurança das crianças e a relação delas com mobilidade, trânsito, estacionamento e ônibus.

Gaivotas. A ponte que faz ligação entre a Rua Jorge Rizk e a Avenida Leila Diniz é inadequada. Não possui ciclovia ou passeio de pedestres adequado. A calçada precária não possui pavimentação. Não há guarda corpo que proteja as crianças na ponte, construída sobre o valão (medievalmente a céu aberto!). Toda a Avenida Leila Diniz necessita de cuidado, desde a rotatória que faz ligação com a Rodovia Darly Santos até o Parque das Gaivotas há carência de ciclovia e passeios adequados. A mão única pode ajudar. (Participante nº 202, grifo nosso).

Se a atenção se voltar para bairro no sentido vertical-sul, a palavra será seguida por região, cidade, município, desenvolvimento, construção, preservação, casa, espaço, pavimentação e comunidade. Isso remete à sugestão de que o bairro precisa estar (verbo exposto no centro) inserido no espaço da cidade e que desenvolvimento está aliado à pavimentação, à iluminação.

Praia de Itaparica. Sugiro que o PDM seja elaborado, consolidado, aprovado e implementado com o foco de tornar nossa Vila Velha uma cidade essencialmente turística. Conheço e frequento nossa cidade há mais de 25 anos e há um ano me aposentei e moro na Praia de Itaparica. Ao longo de todos estes anos que estive em contato com a cidade sempre ouvi avaliações ótimas sobre a qualidade de vida e sempre com foco no turismo. Se tivermos o turismo como foco, todas as melhorias correlatas trarão desenvolvimento. A limpeza, a preocupação social, a segurança, o incentivo a empreendedores. Imaginem uma cidade a $20 \mathrm{~km}$ de um aeroporto e que tenha praias lindas e limpas, escola de kitesurfvisitas seguras e controladas às ilhas, meio ambiente protegido e admirado, três shoppings, alimentação de primeira. Poderemos trazer congressos, excursões de bom nível. As escolas ensinarão às crianças, a economia informal poderá ser bem orientada. Só temos a ganhar! (Participante n 135 , grifo nosso).

Barra do Jucu. Barra do Jucu é uma comunidade tradicional, ocupando um lugar de destaque pelo convívio social e familiar em destaque pelos moradores, onde o "bom dia" do vizinho ainda se faz sentir. Existe pavimentação, à agua e energia, mas tem a carência de ESGOTO SANITÁRIO para seus moradores. Implantar o esgoto é uma necessidade de civilização e de boa saúde para todos. (Participante nº 46, grifo nosso).

Centro de Vila Velha. Projeto de revitalização para a Praça Duque de Caxias, com novas atividades de lazer e cultura, inclusive equipamentos para ginástica, pontos regulares para alimentação e comércio já existentes, baia correta no ponto de ônibus e melhora na pavimentação. Mais segurança com boa iluminação, poda regular de árvores e monitoramento. Dica: há vários projetos feitos por alunos de arquitetura e urbanismo dessa praça que seriam ótimos para contribuir na revitalização. O Centro de Vila Velha merece uma boa praça! (Participante n 93, grifo nosso).

Pavimentação, iluminação, lazer e condições para melhor usufruir da cidade com os direitos básicos assegurados caminham no sentido da promoção do bem-estar do cidadão, influenciando em números que refletem na segurança pública (CARMONA, 2014), como nas reduções de crimes contra o patrimônio e homicídios (FARIAS, 2005). 
Casa está no centro, entre preservação e espaço, próxima à comunidade, corroborando o referencial teórico que afirma que as condições de moradia associadas a exclusão social (MARICATO, 2014), distância entre casa e educação, local de trabalho e falta de lazer (SILVA J., 2010) são remetidas à segurança pública e PDM.

Ponta da Fruta. Minha casa fica longe da creche construída em Balneário e gostaria que criassem uma aqui perto de onde eu moro. (Participante $n^{\circ} 230$ ).

Morada da Barra. Vistoriar o uso e a ocupação do seu entorno, como também o lançamento de esgoto em suas águas. Avançar na proposta da criação da área de preservação e parque, para assegurar a proteção a esta delicada região. (Participante $n^{\circ} 39$, grifo nosso).

No sentido oposto, na lateral direita, menciona-se Itaparica e Costa, seguidas de construção, ocupação e parque. Se na lateral esquerda a ênfase é com direito básicos, como esgoto e proteção, na lateral direita são expostas duas praias (Costa e Itaparica), com palavras pontuais como atividade, parque, conservação e ocupação, relacionando-se a turismo e empreendimentos da construção civil.

Praia de Itaparica. A praia é um dos principais atrativos turísticos de Vila Velha, porém a orla vem sendo ocupada de modo descontrolado, com condomínios fechados com alturas incompatíveis ao ambiente no entorno, causando impactos na qualidade urbana, como sombras na praia, desvalorização do potencial paisagístico da costa e a supersaturação da estrutura viária da orla. Uma sugestão é que essa transição do mar para a cidade ocorra de forma suave, com um parque urbano linear nos terrenos à beira-mar ainda não construídos e ociosos (entre a Av. José Júlio de Souza e a Rodovia do Sol, na Praia de Itaparica), ou seja, um parque público com espaços livres arborizados, permeados com espaços para atividades diversas, conectando a cidade à Reserva de Jacarenema. É de fundamental importância que os terrenos fossem inseridos na Zona de Especial Interesse Ambiental, para fins de proteção e preservação do ecossistema marinho e da restinga ainda presente nessa área privada. Existem instrumentos previstos no Estatuto da Cidade, como as "Operações Urbanas Consorciadas" ou o "Direito de Preempção", que visam entre outros objetivos a "criação de espaços públicos de lazer e áreas verdes" bem como a "proteção de áreas de interesse histórico, cultural ou paisagístico" em áreas privadas. (Participante n 123 , grifo nosso).

Praia da Costa. Transformação do Morro do Moreno em parque ecológico, com a retirada de todas construções irregulares e em área de preservação. Implantar projeto para melhor aproveitamento do potencial turístico do Morro e seu entorno. (Participante n²129, grifo nosso).

Tendo a descrição de uma cidade vista pelo olhar de quem a vivência, com problemas a começar pelos bairros, a estrutura da Nuvem de Palavras confirma, por meio de conhecimento popular-empírico, o que aponta o referencial teórico exposto: relacionando investimentos de grandes empresas, alteração ambiental (SILVA, 2014), áreas de preservação indevidamente ocupadas (ROLNIK, 2000; SILVA R., 2010), espaços públicos bem iluminados e revitalizados com áreas de lazer (CARMONA, 2014) à segurança pública, ainda que indiretamente.

Mesmo sem direcionamento ou indução, a Nuvem de Palavras evidencia que a população associa indiretamente planejamento urbano à segurança pública, quando aponta suas deficiências e necessidades, seus problemas e conflitos, e reivindica as soluções no âmbito da vulnerabilidade socioambiental. Confirmando a hipótese defendida de que segurança pública, no viés da vulnerabilidade socioambiental, foi inserida na discussão popular de forma indireta. 
Ser mencionada de forma indireta não a torna menos relevante, mas traz à voga que a segurança pública, além de complexa, é um tema que pode ser inserido no planejamento urbano com atividades e ações próprias da sua alçada. Contudo, a população participante do processo de revisão do PDM encontra dificuldade em relacioná-lo à segurança pública, por constituir-se um tema difuso que perpassa vários segmentos trabalhados pelo município.

As indicações mencionadas pela população podem ser inseridas nas ações municipais de prevenção ao crime e à violência, já que essas incluem promover o bem-estar das pessoas ao estimularem os laços sociais com medidas que garantam saúde, educação, economia e modificação das condições nas comunidades que levem à infração, à vitimização e à insegurança (XAVIER, 2012).

Por meio da Classificação Hierárquica Descendente (CHD), os textos foram organizados de acordo com seus vocabulários, dividindo-se pelas frequências que formaram as classes (SILVA; SILVA; MENEGON, 2017). Isso permitiu a compreensão das expressões e palavras contidas nos comentários analisando-as a partir de seus lugares e inserções sociais.

Para a estatística contextual, as características devem ser consideradas (CAMARGO; JUSTO, 2013). Nesse cenário, o corpus geral foi formado por 330 textos, separados em 785 segmentos de textos, sendo 739 aproveitados, ou seja, 94,14\% do total seguiram em análise. Emergiram 25.789 ocorrências, as quais 1.908 foram distintas e 1.309 com apenas uma ocorrência, categorizando, assim, o conteúdo em 6 classes.

\section{FIGURA 3}

\section{Síntese do corpus textual}

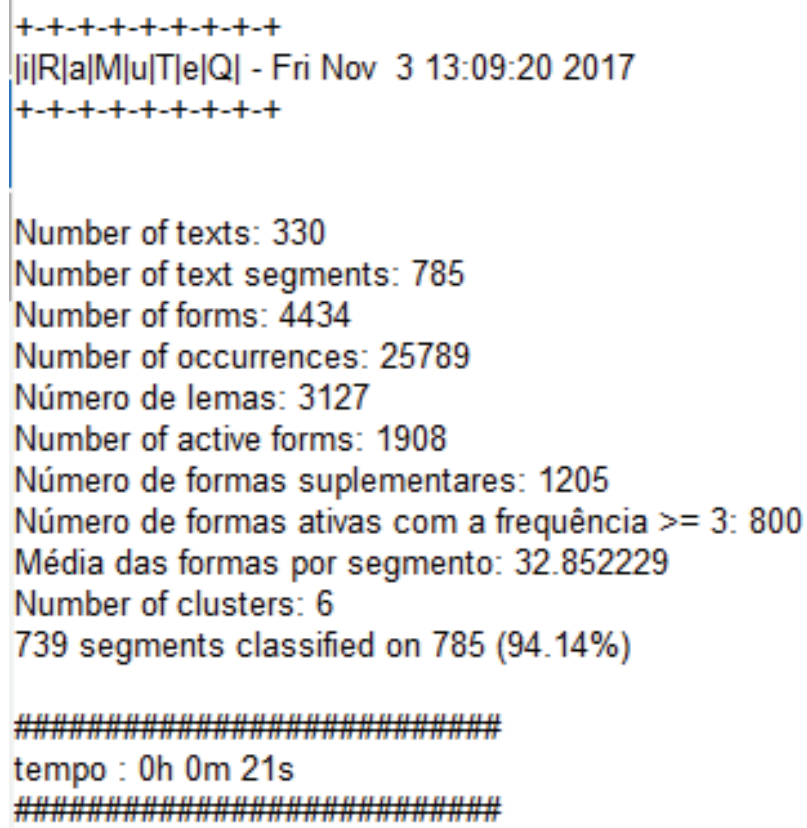

Number of texts: 330

Number of text segments: 785

Number of forms: 4434

Number of occurrences: 25789

Número de lemas: 3127

Number of active forms: 1908

Número de formas suplementares: 1205

Número de formas ativas com a frequência $>=3: 800$

Média das formas por segmento: 32.852229

Number of clusters: 6

739 segments classified on $785(94.14 \%)$

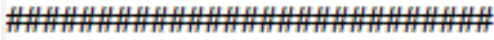

tempo: 0 h $0 \mathrm{~m} \mathrm{21s}$

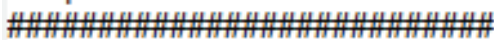

Fonte: Dados da pesquisa.

Conforme a Figura 4, o conteúdo analisado foi categorizado em seis classes: Classe 1, com 98 segmentos de texto, o que correspondeu a 13,30\% do total; Classe 2, com 99 segmentos de texto, representando 
13,40\%; Classe 3, com 182 segmentos de texto, o que representou 24,60\%; Classe 4, com 132 segmentos de texto, representando 17,90\%; Classe 5, alcançando 16\% de segmentos de texto, com total de 118; e Classe 6, que teve 110 segmentos de texto, ou seja, 14,90\% do total.

\section{FIGURA 4}

Dendograma 1 - Classificação Hierárquica Descendente (Vila Velha-ES, 2017)

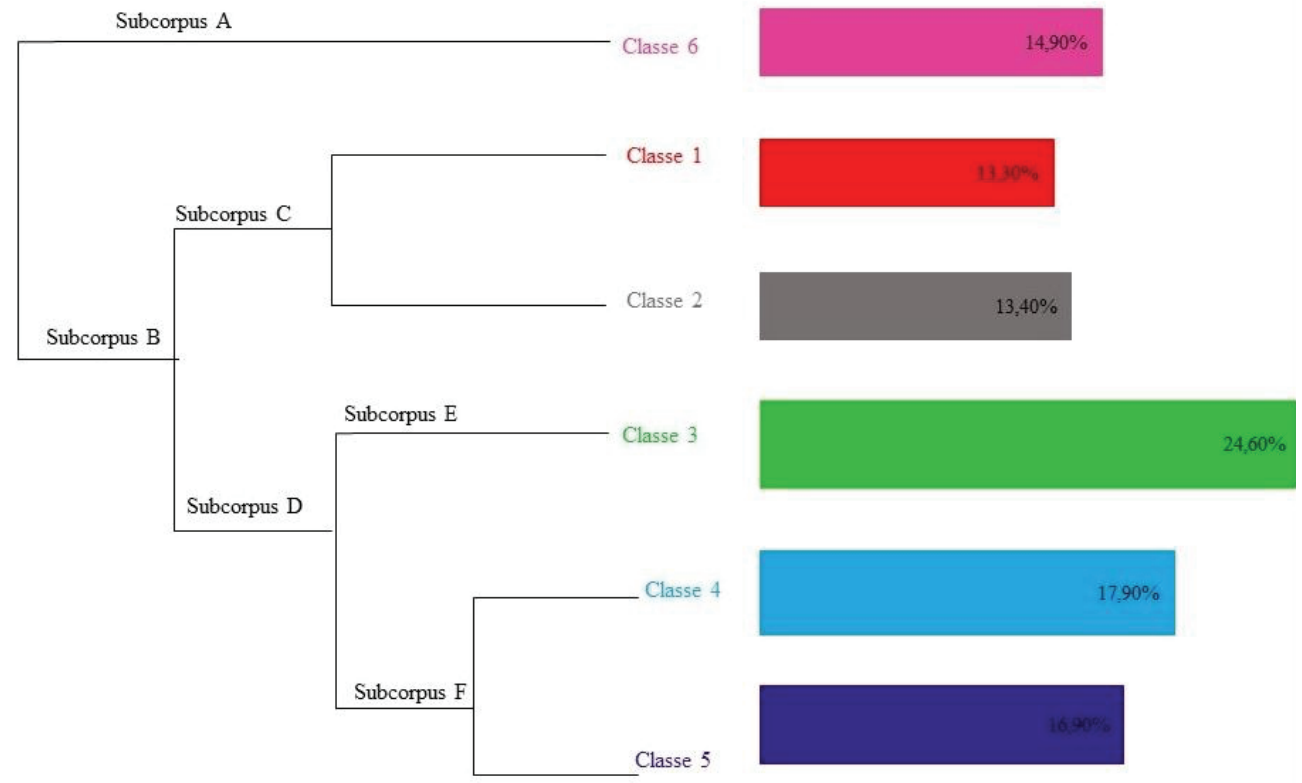

Fonte: Dados da pesquisa.

É válido ressaltar que as seis classes (Figura 4) se apresentaram separadas em ramificações (A e B) do corpus em análise. Da ramificação A, denominada Políticas Públicas, emerge um conteúdo específico compondo a Classe 6, Representação Social. O SubcorpusB, Cidade, é formado pelos Subcorpus C e D, sendo o C denominado Função Social, composto pelas Classes 1, Preservação Ambiental, e 2, Ocupação Regular, e o D denominado Infraestrutura, constituído pelo Subcorpus E, Cidadania, que foi representado pela Classe 3, Cidadania, e pelo Subcorpus F, Desenvolvimento, constituído pelas Classe 4, Mobilidade, e 5, Investimentos em Turismo. 


\section{FIGURA 4}

\section{Dendograma 2 - Classificação Hierárquica Descendente (Vila Velha-ES, 2017)}

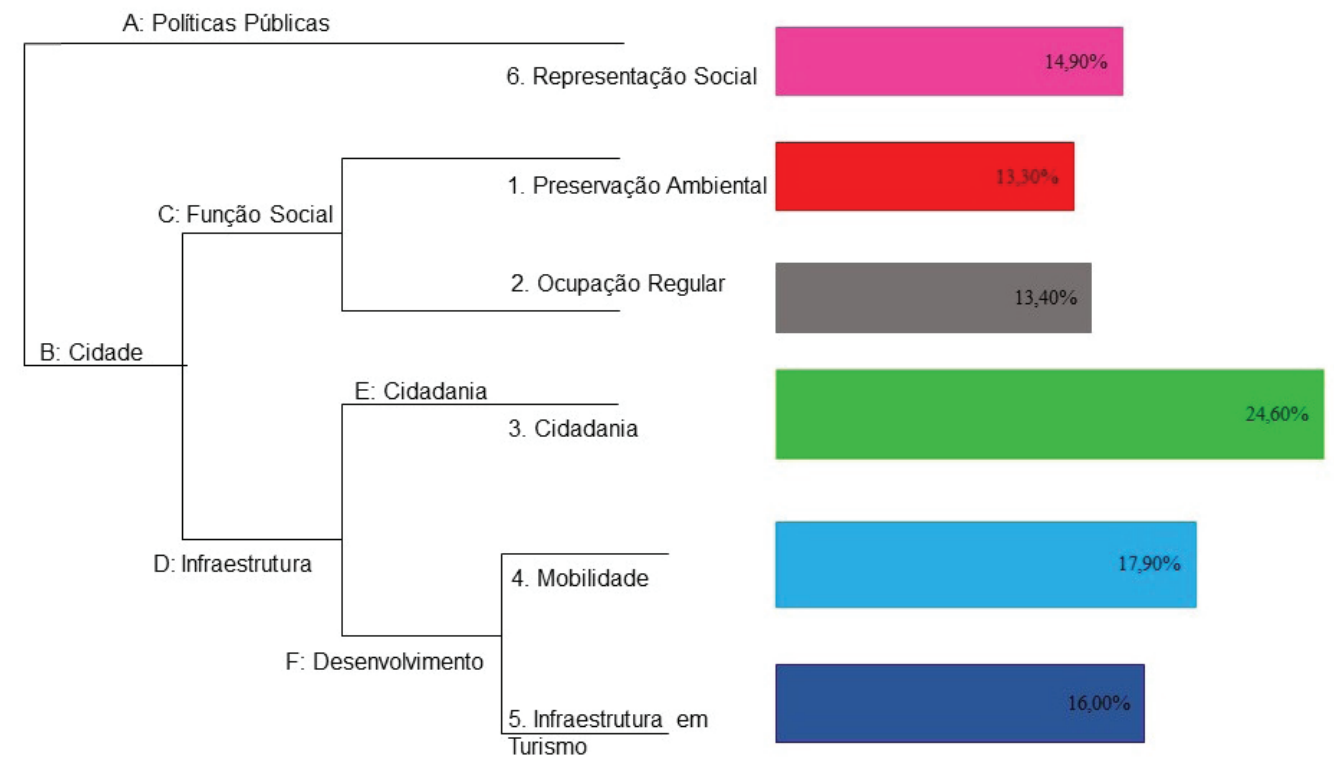

Fonte: Dados da pesquisa.

Destaca-se que essas seis classes se encontram divididas em duas ramificações (A e B) do corpus total em análise. O Subcorpus A, Políticas Públicas, é composto por uma única classe, com conteúdo mais concentrado e distante das demais classes. A Classe 6 (Representação Social) refere-se à participação da sociedade, por meio de conselhos representantes, nas decisões do governo municipal, inclusive em assuntos como economia, desenvolvimento e sustentabilidade. O Subcorpus B, denominado Cidade, é constituído pelos C (Função Social) e D (Infraestrutura), e engloba comentários correspondentes ao planejamento da cidade quanto à propriedade, à regularização e localização, à urbanização e ao transporte/trânsito.

Em continuidade, o Subcorpus C (Função Social) é formado pelas Classes 1 (Preservação Ambiental) e 2 (Ocupação Regular) que, apesar das divergências entre elas, possuem conteúdo comum, por isso estão na mesma ramificação. A Classe 1 retrata a preocupação da população com a preservação do meio ambiente, seja na recuperação de nascente, criação de parques, proteção da fauna, recuperação dos rios. Já a Classe 2, que também expõe assuntos ambientais como parques e zoneamento, enfatiza a ocupação em locais adequados e a regularização das edificações.

Na outra vertente, o Subcorpus D (Infraestrutura) divide-se no E (Cidadania) e no F (Desenvolvimento). A ramificação E organizou-se na Classe 3 (Cidadania), que visualmente associa-se diretamente à segurança pública e faz ligação entre falta de lazer, de iluminação, revitalização com violência, drogas e insegurança.

Por fim, o Subcorpus F (Desenvolvimento) compõem-se das Classes 4 (Mobilidade) e 5 (Investimento-turismo). A similaridade delas está na promoção do desenvolvimento da cidade, com investimentos que conectam o litoral a todo território municipal. A Classe 4 foca-se em indicações de investimentos na orla direcionada ao turismo e ao mercado imobiliário, já a Classe 5 faz referência à melhor organização de trânsito, ao transporte tradicional e o alternativo, como o tema ciclovia. 
Essas ramificações e subdivisões ficam melhor expostas quando as classes são representadas pelas palavras que compõem cada uma, conforme Figuras 5 e 6.

\section{FIGURA 5}

Dendograma 3 - Classificação Hierárquica Descendente (Vila Velha-ES, 2017)

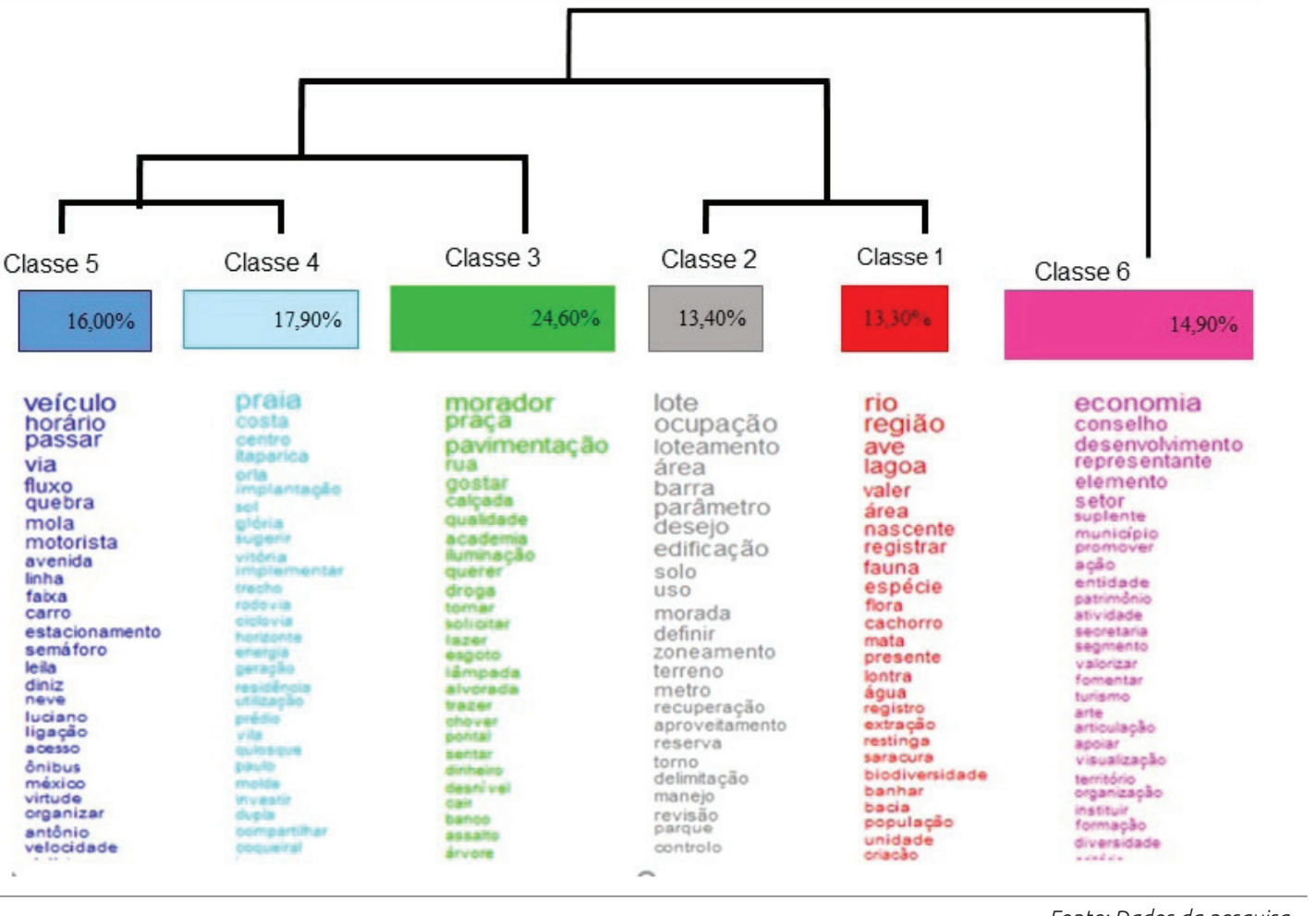




\section{FIGURA 6}

\section{Dendograma 4 - Classificação Hierárquica Descendente (Vila Velha-ES, 2017)}

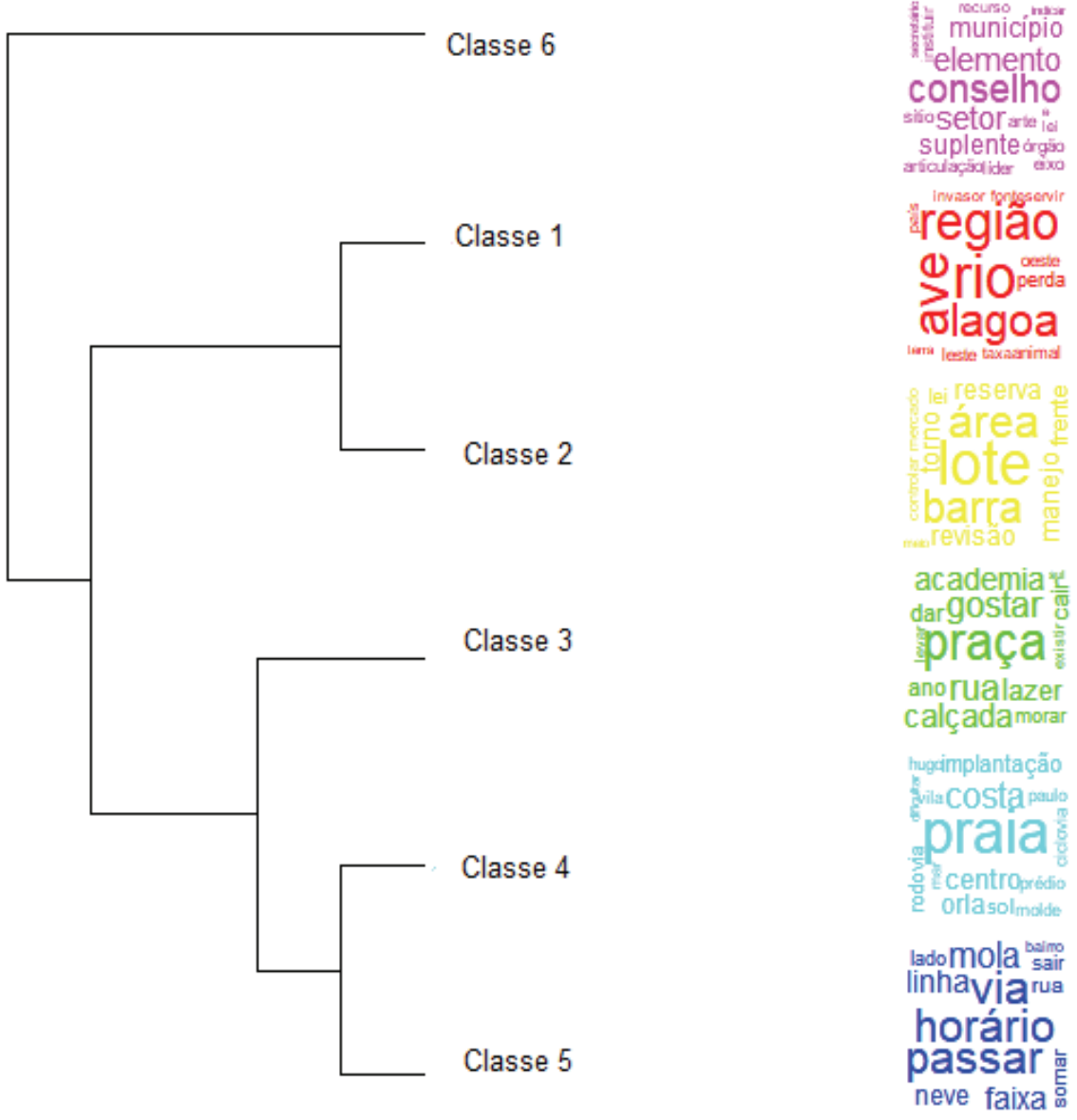

Fonte: Dados da pesquisa.

As Figuras 5 e 6 apresentam categorias que se tornaram nítidas pelos trechos das opiniões, as quais exibem referências que agrupam a significação e o sentido das indicações.

A Classe 6, categorizada como Representação Social, emerge com maior distância das demais, não por indicar uma ruptura entre as mesmas, mas sinalizando uma classe que define as demais. Definição que aponta como responsabilidade daqueles que representam a população no poder público, especificamente na função executiva (Prefeitura Municipal), na efetivação do conteúdo das categorias que se ramificam. Com pertinência, a Classe 6 indica que a sociedade civil deve encontrar-se presente na formulação e organização do território, demonstrando que a população tem ciência que deve fiscalizar seus representantes (SILVA J., 2010). Em contrapartida, os representantes deveriam entender que mais do que administrar finanças, é preciso gerir relações sociais (SOUZA, 2014) e, com isso, oportunizar o equilíbrio entre as necessidades dos moradores que compõem a população do município e sua real condição financeira.

Os segmentos de texto captaram trechos que demonstram esse indicativo: "promover a articulação junto aos órgãos públicos e junto às instituições privadas da inserção da temática da economia criativa no âmbito de suas atuações" (Participante n 132, grifos realizados na análise do Iramuteq). 
A interação e a articulação entre o poder local e a comunidade são essenciais na execução de programas preventivos voltados para a segurança pública (XAVIER, 2012; CARMONA, 2014; MAGALHÃES, 2008).

As Classes 1 e 2 apresentam uma semelhança de valores, com 13,30\% e 13,40\%, respectivamente. A aproximação não se dá apenas em percentuais, mas em conteúdo, suas palavras-chave interlaçam-se em significados e contextos. A Prevenção Ambiental (Classe 1) salienta a preocupação com questões ambientais no sentido de preservar os potenciais naturais do munícipio. Coadunando esse indicativo, a Classe 2 (Ocupação Regular) relaciona ocupação do território com áreas edificáveis, aproveitando o potencial residencial, mas com respeito às áreas de reserva e à delimitação dos zoneamentos.

Classe 1:

Infelizmente a área sofre com queimadas extração criminosa de areia e terra caça captura de aves queimadas criminosas e diversos outros crimes que acontecem comumente a população já utiliza a área para lazer nas lagoas. (Participante $n^{\circ} 34$, grifos realizados pelo Iramuteq).

Vale encantado criação e implementação do parque alagados do vale encanado a área é a região de inundação do rio jucu uma região de alagados que já foram registrados aves raras que somente encontradas na área. (Participante nº 297 , grifos realizados pelo Iramuteq).

Classe 2:

Barra do jucu inserir no pdm regras mais rígidas de uso e ocupação do solo em áreas limítrofes das unidades de conservação principalmente do parque de jacarenema. (Participante $n^{\circ} 16$, grifos realizados pelo Iramuteq).

Uma cidade organizada com normas urbanísticas bem implementadas é fator de segurança (CARMONA, 2014). O planejamento adequado com aproveitamento dos potenciais ambientais e respeito às áreas não edificáveis (SILVA R., 2010), com diminuição dos contrastes urbanos (ROLNIK, 2000) e o não crescimento desordenado (EVANGELISTA, 2012), concorre para a redução das desigualdades sociais e diminui a vulnerabilidade socioambiental (SILVA R., 2010).

Embora não esteja explícito a associação com segurança nessas classes, as reivindicações podem ser trabalhadas com políticas ambientais e sociais que reflitam na segurança. Nesse sentido, reservas naturais e parques urbanos implementados em favor da população podem ser utilizados como áreas de lazer/ recreação, bem como as áreas consolidadas com moradia, avaliadas para a prática de locais seguros, com menos riscos de conflitos de vizinhança por água, divisas e disputas de espaços (FARIAS, 2005). Tais medidas poderiam ter como consequência a redução da segregação urbana, tendo em vista que espaços desvalorizados, dificuldades de locomoção no espaço urbano e deficiência na qualidade da moradia compõem não apenas o cenário de segregação, mas os ambientes vulneráveis a conflitos desencadeadores de violência (CARMONA, 2014).

O conteúdo da Classe 3 evidencia a organização de falas que convergem na direção do referencial teórico no que tange à exclusão social e à segregação urbana; vejamos 
Classe 3:

\begin{abstract}
Mas nesse espaço venho pedir uma melhor iluminação dessa rua já que a rua supracitada possui uma iluminação insuficiente o que a torna um local propício para assaltos trazendo insegurança para todos os moradores espero poder contribuir para tornar vila velha um lugar. (Participante $n^{\circ} 224$, Alvorada, grifos realizados pelo Iramuteq).

A praça que lá existe só tem servido para ponto de usuários de drogas onde o local cheira mal incomodando a vizinhança e os comerciantes além dos moradores da comunidade. (Participante $n^{\circ} 330$, Industrial do Alecrim, grifos realizados pelo Iramuteq).
\end{abstract}

Antigamente iriam construir uma academia popular tinha equipamento e tudo guardado no ginásio do tartarugão mas não sei o que foi feito e a praça não foi terminada a reforma da praça leva qualidade de vida para o bairro sendo que a praça virou depósito de drogas e mendigos. (Participante $n^{\circ} 72$, Itaparica, grifos realizados pelo Iramuteq).

A pmvv podia regularizar esses esgotos junto com a cesan fazer uma ciclovia uma calçada uma praça e colocar uma guarita etc o que não pode é ficar esse valão a céu aberto com os esgotos das casas caindo direto do jeito que está. (Participante n 86, Praia das Gaivotas, grifos realizados pelo Iramuteq).

A análise dos dados indica a predominância de precariedade ou a ausência de serviços públicos em alguns bairros, características de um ambiente em que existe segregação urbana (CARMONA, 2014) e exclusão social (MARICATO, 2014), além de tornar a população desses locais vulneráveis aos atos de violência (SILVA R., 2010) e à não resistência ao crime organizado (CARMONA, 2014). Nesta classe, há assimilação explícita das reivindicações de maior segurança da comunidade que vive nos bairros mencionados.

Nas Classes 4 e 5 há uma afinidade de composição e porcentagem, 17,90\% e 16\%, respectivamente. Elas são compostas por palavras que conectam mobilidade à extensão litorânea da cidade, com a citação de duas praias (Costa e Itaparica). A Classe 5 comporta, ainda, palavras que associam intervenção no trânsito e segurança dos pedestres.

Classe 4:

Centro sugiro e acho que é nosso dever cívico e moral para as futuras gerações implementar áreas verdes na praia da costa que foi destruída pela quantidade enorme e desordenada de prédios alto que impossibilita a circulação do vento e sol na praia. (Participante $n^{\circ} 278$, grifos realizados pelo Iramuteq).

Como sombras na praia desvalorização do potencial paisagístico da costa e a supersaturação da estrutura viária da orla uma sugestão é que essa transição do mar para a cidade ocorra de forma suave com um parque urbano linear nos terrenos à beira-mar ainda não construídos e ociosos. (Participante nº 123, grifos realizados pelo Iramuteq).

Classe 5:

Alvorada venho pedir a instalação de um quebra-molas cidadão nesta rua devido ter uma escola com muitas crianças que saem por essa rua e os motoristas principalmente de ônibus de linha que passa por aqui. (Participante $n^{\circ} 234$, grifos realizados pelo Iramuteq). 
As novas rodovias que dão acesso ao bairro não possuem iluminação pública dificultando a passagem de veículos no período noturno e comprometendo a segurança dos cidadãos que utilizam o caminho nesse horário em nome dos moradores da região peço que realizem e executem um projeto de iluminação. (Participante $n^{\circ} 267$, grifos realizados pelo Iramuteq).

Ainda que as palavras não estabeleçam associação direta à segurança, pode-se inferir sua ligação indireta se entendermos litoral como áreas de circulação e lazer, eixos defendidos por Carmona (2014) a serem trabalhados, a exemplo do que foi realizado na cidade de Bogotá (Colômbia). Não é foco desta pesquisa, mas a mobilidade urbana e a violência no trânsito conectam-se diretamente à segurança pública.

A exposição e a categorização em Classes evidencia com maior ênfase a vulnerabilidade que a população envolvida no processo de revisão do PDM - agora foco da pesquisa - vivencia, relacionando-a tanto pela sociedade civil quanto pelos agentes políticos de forma indireta. Isso possibilita o traçar de políticas públicas de segurança ao identificar as causas indiretas da violência, ou seja, as concausas (CARMONA, 2014) que concorrem para a criminalidade e o ambiente violento.

As concausas, conforme Carmona (2014), são as situações que contribuem para a formação de um ambiente violento, contudo não são vistas num primeiro plano quando se trata de segurança pública, haja vista que se tratam de ações voltadas para a efetivação e a concretização de direitos civis básicos, e não de ações como desarmamento, combate ao tráfico de drogas, furtos, entre outros atos criminosos que assolam a sociedade brasileira. Tratam-se de ações voltadas para o fortalecimento do cidadão, como ambiente seguro com acesso à educação, ao lazer, à cultura, ao emprego, ao saneamento e à preservação adequada dos recursos naturais, ações essas que podem ser iniciadas com um planejamento urbano adequado e eficaz, levando em considerações as peculiaridades, deficiências e os pontos fortes de cada município. São essas ações que são alvo dos anseios e desejos da população, que não as conectam à segurança, contudo o referencial teórico nos conduz ao elo existente entre vulnerabilidade socioambiental, destacando-se as exclusões sociais e territoriais e a segurança pública preventiva.

A partir disso, a Classificação Hierárquica Descendente sugere que as reivindicações da população não se coadunam em sua totalidade com as funções de um PDM, mas expõem a vivência em áreas acometidas por exclusão social, exclusão territorial e segregação urbana, o que a torna (a população) vulnerável a situações de conflito e violência (ROLNIK, 2000; SILVA R., 2010; CARMONA, 2014).

A Figura 7 exibe os dados da Análise de Similitude, que expõe a identificação das ocorrências simultâneas entre as palavras e a conexidade entre os termos encontrados nas indicações populares. A importância está na possibilidade de inferir a estrutura de construção do texto e os temas de relativa relevância. Na figura, as palavras de maior interação estão organizadas em blocos de cores diferentes, os termos que apresentam conexidade são: ter, cidade, ir, praia, morador, bairro, área e região. É possível notar as oposições estabelecidas pelo distanciamento como em ônibus e qualidade. Observa-se, ainda, que das palavras centrais são estabelecidas ramificações com outras, como: ter, cidade, poder, estar, casa, morador, região, parque, área; atividade, economia, desenvolvimento; bairro, pavimentação, espaço.

Nesse sentido, pode-se inferir que, de forma geral, os comentários dos participantes apresentam fragmentos de seus problemas pontuais vivenciados dia a dia e esses interligam-se ao referencial na medida que a estruturação das comunidades, a começar pelos bairros, diminui a vulnerabilidade, ou seja, a exposição ao perigo dos moradores desses locais (CARMONA, 2014). 


\section{FIGURA 7}

\section{Análise de Similitude}

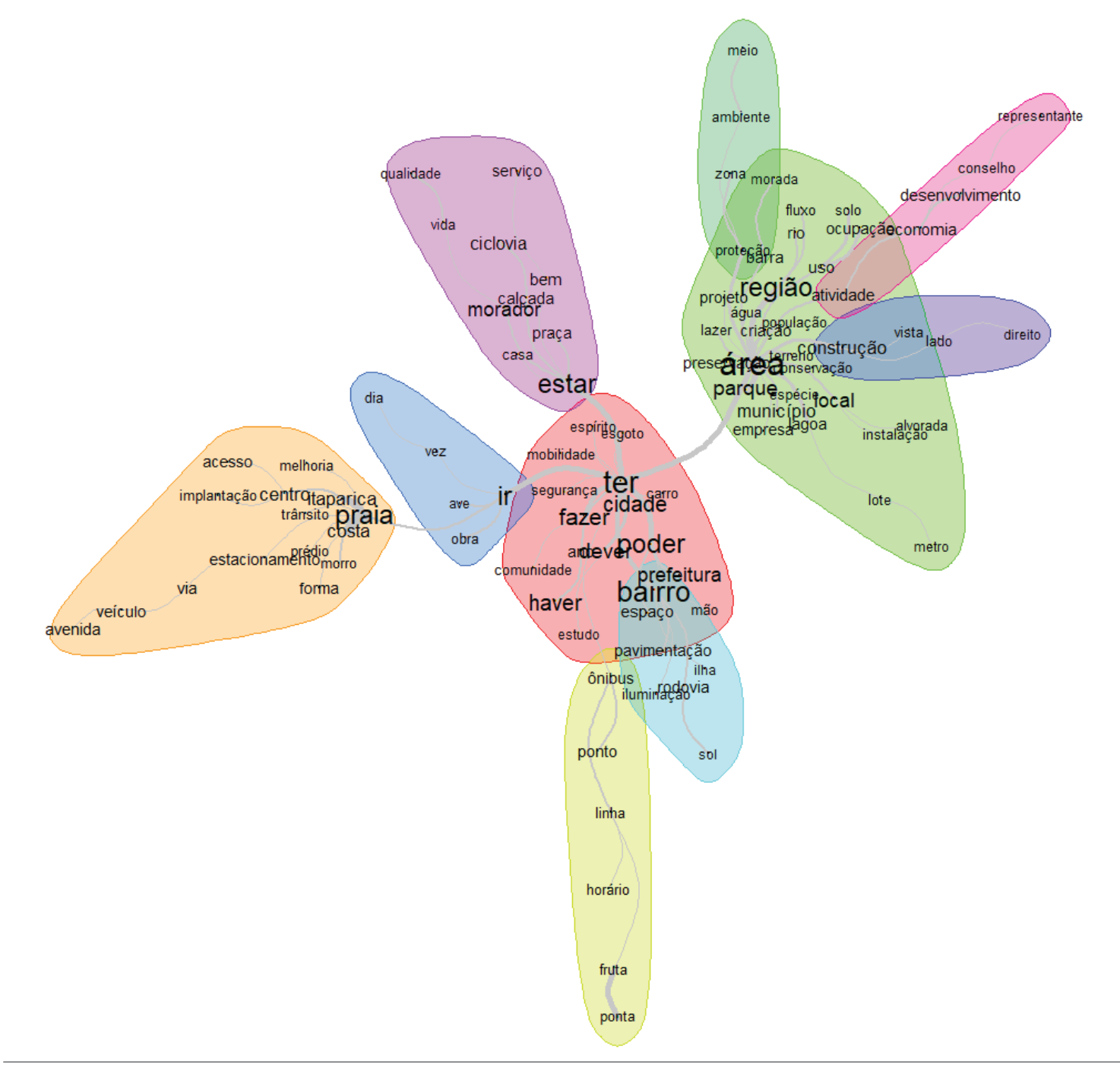

Fonte: Dados da pesquisa

As ramificações construídas em blocos de palavras demonstram eixos que especificam as necessidades associadas à intervenção que pode haver do poder público. Contudo, mais uma vez, lança o morador, cidadão, como figura a ser consultada e agente participante das intervenções propostas. Essa participação voluntária (SOUZA, 2010) é essencial para a consolidação da gestão democrática (FERNANDES, 2013) e a sua inserção no planejamento de políticas públicas de segurança.

As palavras foram agrupadas em raízes que conduzem à formação de uma árvore, relacionando-as aos segmentos de uma cidade, à distância entre qualidade, ciclovia, serviço e morador, e sugerem não haver qualidade no percurso enfrentado pelos moradores entre suas casas e o local de serviço. Em outra raiz, segurança distancia-se de espaço, bairro e estudo, sugerindo a falta ou a carência de segurança nos bairros. A proximidade de segurança, mobilidade e esgoto remete que a população faz ligação entre essas áreas 
e enfrentam com problemas de locomoção, de saneamento, infraestrutura e enxergam reflexos na segurança pública desses enfrentamentos.

As ramificações apontam, por fim, que a segurança pública, quando se trata de implicações à vulnerabilidade socioambiental, é abordada de forma indireta pela população e pelos agentes políticos condutores do processo, já que não expõe especificamente os problemas de violência e crimes, comumente abordados na temática Segurança Pública.

\section{CONSIDERAÇÕES FINAIS}

O objetivo deste estudo se constitui na análise da participação popular na revisão do Plano Diretor Municipal. Para isso, partiu-se de uma análise de conteúdo da participação popular, em plataforma on-line, na discussão de revisão do Plano Diretor Municipal de Vila Velha-ES. Os resultados indicaram, na análise da plataforma on-line, na Nuvem de Palavras, que mesmo sem direcionamento ou indução, a população associa indiretamente planejamento urbano à segurança pública, quando aponta suas deficiências, necessidades, seus problemas e conflitos, e reivindica as soluções no âmbito da vulnerabilidade socioambiental. Contudo, há dificuldade em relacioná-los por constituírem-se temas difusos que perpassam vários segmentos trabalhados pelo município.

Na Classificação Hierárquica Descendente seis classes interligadas surgiram: Políticas Públicas, que ofereceu base para todas as outras classes e, no outro extremo, Cidade, emergindo com as classes Preservação Ambiental e Ocupação Regular, que apresentaram o mesmo grau de significância no corpus, mas revelaram-se, também, as classes Cidadania, Mobilidade e Investimento em Turismo.

As classes formadas, a Nuvem de Palavras e a relação das categorias confirmaram a hipótese defendida de que o tema Segurança Pública foi abordado de maneira indireta, por meio de problemas pontuais que afligem a população, não expressados em falas sobre violência ou criminalidade, mas trazendo à tona questões que descrevem também um cenário de vulnerabilidade socioambiental e que, se priorizadas e solucionadas, influenciariam no combate à violência e à criminalidade.

Quanto à cidade, seus problemas e suas propensas resoluções são detalhadas por seus moradores os quais têm uma visão mais realista (SILVA, J.,2010), e não apenas uma lei que contenha princípios e diretrizes que projetam cidades a serem construídas. A função social da cidade e da propriedade proposta pelo Estatuto da Cidade busca trabalhar conflitos de moradias, preservação ambiental, áreas de risco e ausência de terrenos destinados a residências acessíveis. Se o município que possui papel fundamental nas políticas públicas de segurança (MAGALHÃES, 2008) enxergar seus problemas pontuais, é um caminho para a concretização de uma cidade mais segura.

Apesar de contribuições e implicações, a pesquisa também apresenta limitações que devem ser mencionadas. A análise foi realizada em uma única etapa do processo de revisão, não foi possível estudar os problemas descritos com os índices de violência de cada bairro e não foram realizadas entrevistas e visitas aos locais apontados nos documentos, como as áreas de vulnerabilidade socioambiental. Nesse contexto, recomenda-se que futuras pesquisas sejam realizadas de forma que envolva diretamente o cenário descrito com vulnerabilidade, associado aos problemas já existentes de violência e criminalidade. 


\section{REFERÊNCIAS BIBLIOGRÁFICAS}

CALDEIRA, T. Cidade de muros. Crime, segregação e cidadania em São Paulo. São Paulo: Ed. 34/Edusp, 2000.

CAMARGO, B. V.; JUSTO, A. M. IRAMUTEQ: um software gratuito para análise de dados textuais. Temas em Psicologia, v. 21, n. 2, p. 513-518, 2013.

CAMORNA, P. A. C. Violência x cidade: o papel do direito urbanístico na violência urbana. 1 ed. São Paulo: Marcial Pons; Brasília, DF: Fundação Escola Superior do Ministério Público do Distrito Federal e Territórios, 2014.

CARDIN, V. S. G.; MOCHI, T. de F. G. Public polices for prevention of violence against children and adolescents within the family. 2014. Disponível em: http://www.publicadireito.com.br/ artigos/?cod=05edf455cb266ccb. Acesso: 01 de novembro de 2017.

ESTEVES, C. J. O. Risco e vulnerabilidade socioambiental: aspectos conceituais. Caderno Ipardes, v. 1, n. 2, p. 62-79, 2011.

EVANGELISTA, F.C.F. A Criminalidade e o Planejamento Ambiental Urbano. Veredas do Direito: Direito Ambiental e Desenvolvimento Sustentável, v. 9, n. 17, p. 197, 2012.

FARIAS, C. C.; ROSENVALD, N. Curso de Direito Civil. Teoria Geral. 2 ed. Rev. Ampl. e Atual. São Paulo: Atlas, 2015.

FARIAS, P. J. L. Ordem urbanística e a prevenção da criminalidade. Revista de Informação Legislativa, Brasília, Senado Federal, ano 42, n. 168, p. 167-183, out./dez. 2005.

FERNANDES, E. Estatuto da Cidade, mais de 10 anos depois. Revista da Universidade Federal de Minas Gerais, v. 20, ก. 1, 2013.

FREITAS, C. M. de; CARVALHO, M. L. de; XIMENES, E. F.; ARRAES, E. F.; GOMES, J. O. Vulnerabilidade socioambiental, redução de riscos de desastres e construção da resiliência: lições do terremoto no Haiti e das chuvas fortes na Região Serrana, Brasil. Ciência \& Saúde Coletiva, v. 17, n. 6, p. 1577-1586, 2012.

LIMAS, R. S; BUENO, S. (Coord.); Anuário Brasileiro de Segurança Pública 2016, 2016.

MAGALHÃES, Luiz Carlos. O Poder Municipal e a Segurança Pública. Revista IOB, 2008.

MARICATO, E. O impasse da política urbana no Brasil. 3 ed. Petrópolis, RJ: Vozes, 2014.

MENDONÇA, F. Riscos, vulnerabilidades e resiliência socioambientais urbanas: inovações na análise geográfica. Revista da Anpege, v. 7, n. 1, p. 111-118, 2017.

OMS - ORGANIZAÇÃO MUNDIAL DA SAÚDE. Relatório mundial sobre violência e saúde. Editado por KRUG, E. G. et al. Genebra: Organização Mundial da Saúde, 2002.

ROLNIK, R. Exclusão Territorial e Violência: o caso do Estado de São Paulo. Cadernos de Textos, Belo Horizonte, v. 2, p. 173-196, ago. 2000.

SILVA, J. A. Direito urbanístico brasileiro. 6 ed. Rev. e Atual. São Paulo, SP: Malheiros, 2010.

SILVA, J. A. T. e. Cidades, resiliência e direitos fundamentais: uma articulação necessária em função das mudanças climáticas. Revista de Direito Ambiental, ano 20, v. 84, out./dez. 2016.

SILVA, L. dos S. da. Análise da segurança pública sob a ótica socioambiental em atividade causadora de significativa degradação ambiental. 2014. Dissertação (Mestrado em Direito Ambiental) - Escola Superior Dom Helder Câmara, Belo Horizonte, 2014. 
SILVA, R. C. M. da. Violência, Vulnerabilidade e Exclusão Socioespacial: uma revisão conceitual. In: Anais... $1^{\circ}$ Encontro Nacional da Associação Nacional de Pesquisa e Pós-graduação em Arquitetura e Urbanismo. Enanparq, Rio de Janeiro, 29 nov./3 dez. 2010.

SILVA, J. R. da; SILVA, Q. A. D. da; MENEGON, V. G. e S. A atuação da enfermagem no programa saúde na escola: o desafio do trabalho em rede. Reas - Revista Eletrônica Acervo Saúde, v. supl. 6, p. 461-468, 2017.

SOUZA, M. L. Mudar a cidade: uma introdução crítica ao planejamento e à gestão urbanos. 6 ed. Rio de Janeiro, RJ: Bertrand Brasil, 2010.

VILA VELHA. Prefeitura Municipal. Relatório: etapa 2 - Leitura Comunitária. Novo PDM Vila Velha. Vila Velha-ES, 2016. 55 p. Disponível em: www.vilavelha.es.gov.br/pdm. Acesso em: 1 nov. 2017.

VILLAÇA, F. São Paulo: urban segregation and inequality. Estudos Avançados, v. 25, n. 71, p. 37-58, 2011.

XAVIER, L. N. Novas Doutrinas e Política de Segurança Pública. In: Anais... $21^{\circ}$ Encontro Nacional do Conpedi. Florianópolis: Publica Direito, v. 1. p. 7259-7289, 2012. 


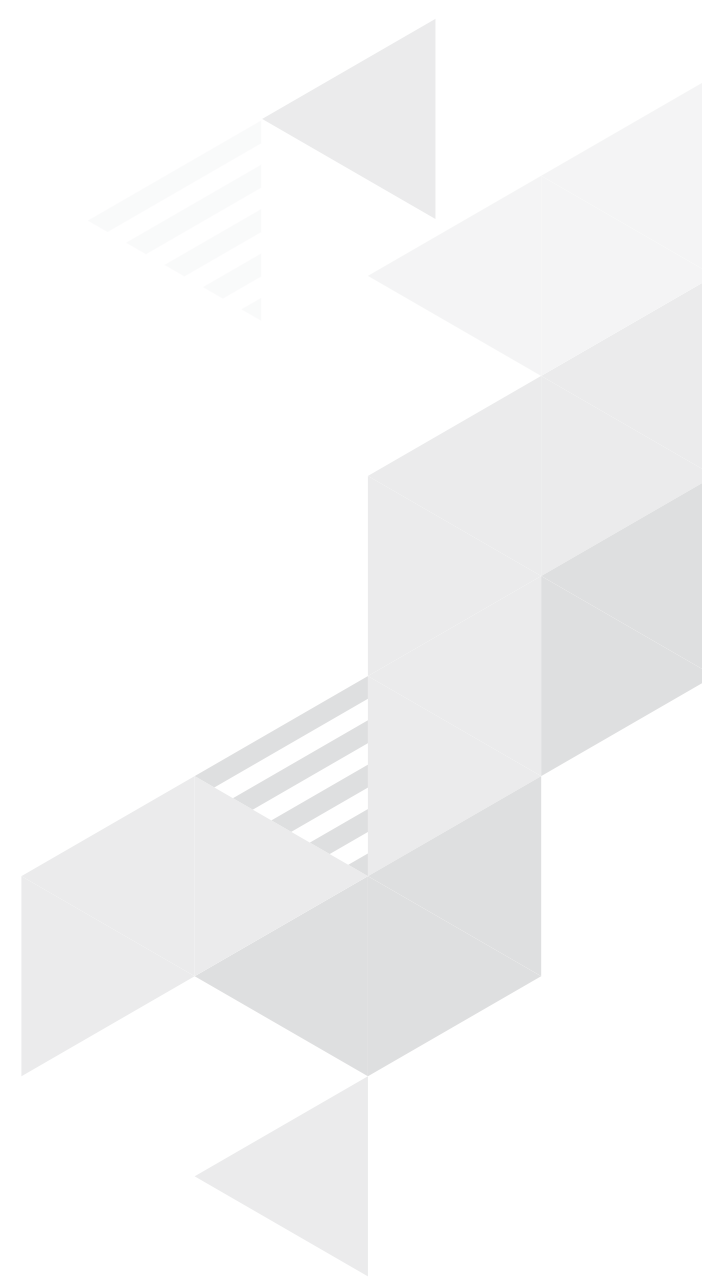

